${ }^{\odot}$ Entomologica Fennica. 19.X.1992

\title{
Revision of the species of Meromyza Meigen (Diptera, Chloropidae) from Finland
}

\author{
Emilia P. Nartshuk
}

Nartshuk, E. P. 1992: Revision of the species of Meromyza Meigen (Diptera, Chloropidae) from Finland. — Entomol. Fennica 3:121-138.

The Finnish species of the genus Meromyza are revised. Three new species $M$. ingrica sp. n., M. lidiae sp. n. and M. zimzerla sp. n. are described using material from adjacent parts of Russia, Estonia and Latvia. The total number of Finnish Meromyza species is 16. Illustrations of the male genitalia, maps of records in Finland for all the species and a key to the known species from Finland are provided.

Emilia P. Nartshuk, Zoological Institute, Academy of Sciences of Russia, St. Petersburg, Russia

\section{Genus Meromyza}

Meromyza is one of the largest genera of Chloropidae, with about 80 valid species. The genus is mainly Holarctic in distribution with a large majority of the species known from the Palearctic. The genus is characterized as follows. Body elongated, 3-7 mm long, mostly greenish or yellow in colour with 3-5 black or redbrownish longitudinal stripes on mesonotum, scutellum usually with black stripe. Abdomen and pleura with dark stripes and marks. Chaetae few and minute. The 3 rd antennal segment mostly rounded, arista slender with minute pubescence. Wing hyaline with veins $R_{2+3}$ and $R_{4+5}$ strongly concave forward. Hind femur strongly thickened and bears 2 rows of small black warts on ventral side; hind tibia correspondingly curved. A remarkable feature of the genus is the rather strongly sclerotized, usually black, gonite in the male genitalia. Its form is important for distinguishing of species.

The forward strongly concave veins $\mathrm{R}_{2+3}$ and $\mathrm{R}_{4+5}$, the thickened hind femora and the sclerotized gonites in the male genitalia I consider as apomorphic features of Meromyza. The genus is a monophyletic group.

The members of the genus are associated with Gramineous plants, in the shoots of which the phytophogous larvae develop. 13 genera of Poaceae are known as host plants of Meromyza (Nartshuk 1972). The flies are rather common on dry and wet meadows; they are xerophilous and mesophilous and do not occur on marshes with Carex.

The species of the genus are rather similar in general appearence and cannot be determined without dissection and investigation of the male genitalia. Females of most of the species cannot be identified with certainty. L. I. Fedoseeva proposed to use the form of the gonite in lateral view for distinguishing the species. However, in my study of Meromyza from Finland and the north-western part of the Russia I found that while some species have a very similar gonite form, they can be easily distinguished by other parts of the male genitalia viz. surstylus and phallus. On this basis two new species $M$. zimzerla 
sp. n. and $M$. lidiae sp. n., closely related to $M$. variegata $\mathrm{Mg}$. and $M$. laeta $\mathrm{Mg}$. respectively, are described. The third new species belongs to the "pratorum" group. For the new species I use additional material from the territory of Russia, Estonia, Latvia and Bulgaria.

This paper is based mainly on the material from the collection of the Zoological Museum, University of Helsinki. I have added the Finnish material collected by myself in Espoo (South Finland) in 1985. The total number of specimens determined is nearly 650, most of them from Finland.

Only 3 species of Meromyza were listed in the check-list of Finnish Diptera (Hackman 1980). The total number of species of Meromyza now known from Finland is 16, of which 13 species are newly recorded from the fauna. The list of species without places and dates has been published (Nartshuk 1988).

Nearly all the species recorded in Finland are rather widespread. Three species $M$. saltatrix, $M$. pratorum and $M$. nigriventris are Holaretic. It is worth mentioning that $M$. nigriventris, a wellknow pest of wheat, is very rare in Finland and found only in four places. One species, $M$. sororcula, has trans-palaearctic distribution. Three species, viz. M. curvinervis, $M$. nigriseta and $M$. pluriseta, have a euro-siberian range, ranging from Europe to Jakutia or Mongolia. The other 9 species are European.

Three species are the most abundant in the collection, i.e. M. saltatrix, $M$. pratorum and $M$. sororcula; , another three, viz. $M$. pluriseta, $M$. palposa, $M$. triangulina are common, and the rest are rather rare.

The material available has been collected mostly in the southern part of the country and is insufficient for a discussion of the distribution of species within Finland. The find localities for Finland are, however, presented as UTM-maps in the Appendix, p. 137-138.

$M$. saltatrix is the most common and reaches the northern limit of the country. M. sororcula, $M$. pratorum, $M$. ingrica sp. n., $M$. pluriseta and $M$. palposa are known from the southern and central parts, and the other species for the present are found only in the southern part. All the species have been mapped.
Table 1 lists the Meromyza species from Finland, Estonia, Latvia and the St. Petersburg region. The table is based on published (Stackelberg 1965, Nartshuk \& Elberg 1979, Karps 1981) and new data. The local European Meromyza fauna consists of 14-16 species. Thus, 16 species of Meromyza are recorded for England (Ismay 1980), for Hungary (Dely-Draskovits 1978) and for Bulgaria (Beschovski 1985).

The Meromyza fauna of the four territories compared is rather similar. M. elbergi, described from Estonia and found in Finland, seems to be found in the St. Petersburg region. M. rostrata is a rather rare species described from Poland (Hubicka 1966). I think it may well be found in Estonia and the St. Petersburg region. M. sibirica is rather common in Siberia, but is rare and known in the European part of Russia only from isolated finds. It is possible that $M$. sibirica may be found in Finland. M. femorata, M. rufa, $M$. smirnovi and $M$. zachvatkini have a more southern distribution. The two former are not found North of

Table 1. List of Meromyza species known from Finland, Estonia, St. Petersburg region, and Latvia.

\begin{tabular}{|c|c|c|c|c|}
\hline & Fin & Est & StP & Lat \\
\hline M. curvinervis Zetterstedt & + & + & + & + \\
\hline M. elbergi Fedoseeva & + & + & - & + \\
\hline M. ingrica sp. $\mathrm{n}$. & + & + & + & - \\
\hline M. femorata Macquart & - & - & - & + \\
\hline M. lidiae sp. n. & + & - & + & - \\
\hline M. mosquensis Fedoseeva & + & + & + & + \\
\hline M. nigriseta Fedoseeva & + & + & + & + \\
\hline M. nigriventris Macquart & + & + & + & + \\
\hline M. palposa Fedoseeva & + & + & + & + \\
\hline M. pluriseta Péterfi & + & + & + & + \\
\hline M. pratorum Meigen & + & + & + & + \\
\hline M. rohdendorfi Fedoseeva & + & + & - & + \\
\hline M. rostrata Hubicka & + & - & - & - \\
\hline M. rufa Fedoseeva & - & - & - & + \\
\hline M. saltatrix Linnaeus & + & + & + & + \\
\hline M. sibirica Fedoseeva & - & + & + & - \\
\hline M. smirnovi Fedoseeva & - & + & - & - \\
\hline M. sororcula Fedoseeva & + & + & + & + \\
\hline M. triangulina Fedoseeva & + & + & + & + \\
\hline M. zachvatkini Fedoseeva & - & + & - & - \\
\hline M. zimzerla Fedoseeva & + & + & + & + \\
\hline Number of species & 16 & 16 & 14 & 15 \\
\hline
\end{tabular}


Latvia; in Estonia the two latter have been recorded only in the south-eastern part in dry sandy places. This seems to be the most northern record for these two species.

In the following key of the Finnish species M. sibirica, which may be found in Finland, is included. The key is illustrated by drawings of the male genitalia of all species included. In addition drawings of the male genitalia of $M$. variegata Meigen and $M$. laeta Meigen are given for appropriate comparison with the new species $M$. zimzerla and M. lidiae.

\section{Key to Finnish species of Meromyza (males only)}

1. Palpi pale, at most only the tip a little darkened ...... 2

- Palpi largely black, at least on apical half ................ 7

2. Abdomen with a central dark stripe and two dark lateral spots at the base, no lateral dark spot on tergites $3-5$; surstylus rather long and expanded medially with long hairs

- Abdomen with three dark stripes or nearly black dorsally. Surstylus different ..................................... 5

3. Phallus swollen at base, basally nearly twice as broad as at middle. Lower margin of anterior process of gonite strongly convex medially, the tip of anterior process turned a little laterally. Frons distinctly produced, hypopleural marks yellow to reddish. Genitalia Fig. 11 ................................................ M. pratorum

- Phallus not swollen at base, basally not broader than at middle. Lower margin of anterior process of gonite more straight and not turned laterally. Frons less produced and hypopleural mark black ......

4. Lower margin of anterior process of gonite a little convex and the tip less pointed. Genitalia Fig. 3

M. ingrica

- Lower margin of anterior process of gonite more straight and the tip pointed. Genitalia Fig. 16 .....

M. sororcula

5. The hind femur more swollen; it is 4 times as wide as the hind tibia. Genitalia Fig. 12 .......... M. rohdendorfi

- The hind femur less swollen and only 2.5-3 times wider than the hind tibia. Genitalia different ........... 6

6. Central mesonotal stripe does not extend to the scutellum. Surstylus long and directed laterally at tip. Genitalia Fig. 19 M. zimzerla

- Central mesonotal stripe extends over the scutellum. Surstylus shorter and straight. Genitalia Fig. 6 M. mosquensis

7. Frontal triangle with its boundary linearly darkened. Cheek with black hairs
- Frontal triangle not darkened laterally. Cheek without black hairs ........................................................ 9

8. Frontal triangle 1.5 times higher than broad at base, with concave lateral sides, and wrinkled surface. Gonite more massive, the posterior process long. Genitalia Fig. 2 ...................................................... elbergi

- Frontal triangle nearly equilateral, with straight lateral sides. Gonite small. Genitalia Fig. 17 . M. triangulina

9. Anterior process of gonite elongated and pointed at the tip. 10

- Anterior process of gonite broad at the tip, sometimes the tip depressed and turned laterally, gonite more massive ................................................................ 16

10. Posterior process of gonite long and directed posteriorly, basal part of phallus swollen and nearly square. Central mesonotal stripe ending before the scutellum. Genitalia Fig. 1 ..................... curvinervis

- Posterior process of gonite shorter and directed downwards or a little anteriorly, sometimes hardly separated from the anterior one. Phallus not swollen basally.

11. Gonite scarcely darkened, nearly transparent or a little brown, posterior process small, sometimes hardly separated from the anterior one. Hind femur more swollen, nearly 3 times wider than hind tibia ........ 12

- Gonite more strongly sclerotized dark brown or almost black, the posterior process well developed. Hind femur usually less swollen, not more than 2-2.5 times wider than hind tibia ...................................................... 14

12. Surstylus rather narrow and has a group of black thickened bristles at the base. Genitalia Fig. 7 ........... M. nigriseta

- Surstylus moderately broad, sometimes long without black thickened bristles 13

13. Surstylus longer than epandrium. Anterior process of gonite more elongated and directed downwards. Central mesonotal stripe ends before the scutellum. Genitalia Fig. 15 ................................................ sibirica

- Surstylus shorter than epandrium, anterior process of gonite shorter and directed anteriorly. Central mesonotal stripe extends to the scutellum. Black spot on ocellar triangle elongated anteriorly. Genitalia Fig. 10 M. pluriseta

14. Surstylus rather broad, gonite small. Genitalia Fig. 9 . M. palposa

- Surstylus more narrow, expanded medially, more elongate 15

15. Anterior process of gonite more massive. Genitalia Fig. 8 ................................................... nigriventris

- Anterior process of gonite more narrow and long. Genitalia Fig. 13 ..................................... M. rostrata

16. Gonite more massive, the tip of anterior process depressed. Surstylus expanded medially. Phallus broadened basally. Genitalia Fig. 14 ................ M. saltatrix

- Gonite more narrow, not depressed at the tip of anterior process. Surstylus long, turned a little laterally. Phallus with a process basally. Genitalia Fig. 5 ....... M. lidiae 

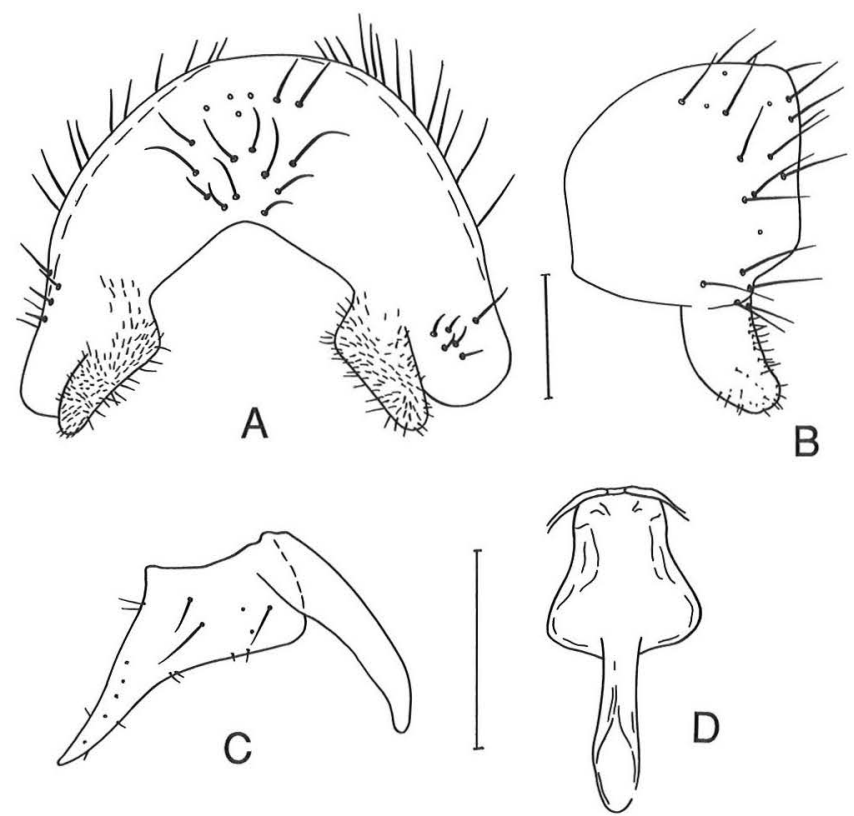

Fig. 1. Meromyza curvinervis Zetterstedt. $-\mathrm{A}=$ epandrium, apical view; $\mathrm{B}=$ epandrium, lateral view; $\mathrm{C}=$ gonite, lateral view; $\mathrm{D}=$ phallus. Scale bars $0.1 \mathrm{~mm}$ (short bar $A$ and $\mathrm{B}$, long bar $\mathrm{C}$ and $\mathrm{D}$ ).

\section{List of species}

\section{Meromyza curvinervis Zetterstedt}

Fig. 1

$A b$ : Dragsfjärd, Nykyrka (= Kalanti).

Russia. Ka: Lavansaari (= Moshshny Island). $-I k$ : Kuokkola (= Repino). Total 40̛' $\sigma^{7}$.

Colour of the body yellow. The central mesonotal stripe ends before the scutellum, but one specimen from 4 investigated has a dark mark with indistinct borders before the scutellum which reaches the scutellum. Abdomen with only the central reddish-brown stripe. Mesonotal stripes black, heavily dusted.

The species was described from Sweden (Gotland, Torsborg), and the type specimen was examined by H. Andersson (1966), who designated the lectotype. The species is widespread from the British Isles to western Mongolia but is everywhere rare. J. W. Ismay (1980) found a single specimen in the British Isles. In Estonia only 4 specimens were found in 3 places (Nartshuk \& Elberg 1979). Eleven specimens are known from the St. Petersburg region (Stackelberg 1965).

\section{M. decora Frey}

The species was described from Finland by R. Frey (1908). Type-locality: Tavastia bei Kangasala. The type specimen in the Zoological Museum of the University of Helsinki, labelled "Kangasala R. Frey spec. type N 4333: Meromyza decora Frey", is a female. It was examined by J. W. Ismay (1980) and he considered it to belong to the $M$. palposa group. O. Duda (1933) synonymized $M$. decora with $M$. pratorum Meigen and, in the Catalogue of Palaearctic Chloropidae (Nartshuk 1984), I synonymized it with $M$. variegata Meigen. The question seems to be insoluble and $M$. decora Frey has to be considered as an uncertain species.

\section{M. elbergi Fedoseeva}

Fig. 2

\section{$A l$ : Lemland. $20^{7} 0^{7}$.}

The species was known from Estonia and Latvia, and is a new record for the Finnish fauna. 
Fig. 2. Meromyza elbergi Fedoseeva. - $\mathrm{A}=$ epandrium, apical view; $\mathrm{B}=$ epandrium, lateral view; $\mathrm{C}=$ gonite, lateral view; $\mathrm{D}=$ phallus. Scale bars $0.1 \mathrm{~mm}$ (short bar $A$ and $\mathrm{B}$, long bar $\mathrm{C}$ and $\mathrm{D}$ ).
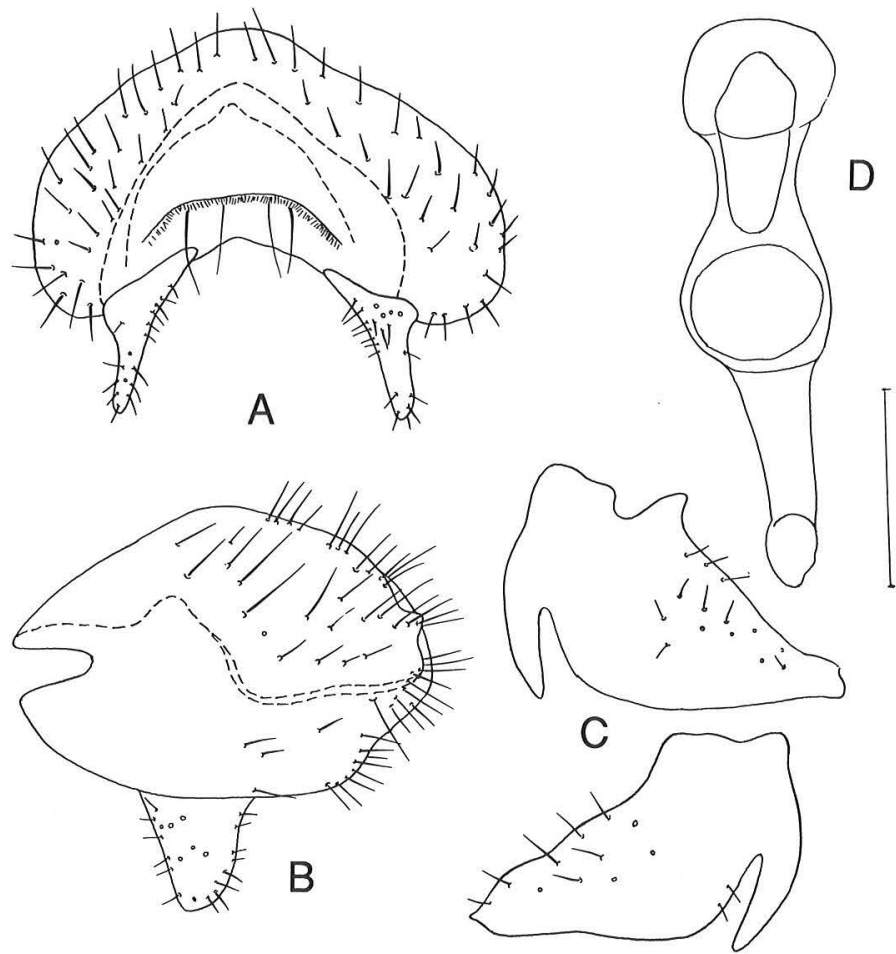

D

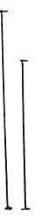

\section{M. ingrica sp. n.}

Fig. 3

Holotype: ơ, Russia, St. Petersburg region, Bolshoi Island Beresovyi in Gulf of Finland, 12.VII.1981 (Kandybina). - Paratypes: $10^{7}$, the same label. Finland:

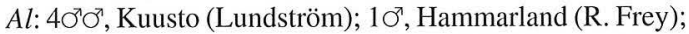
10', Lemland (R. Frey). Ab: 10', Lojo, 1945 (Krogerus); 10', Karislojo (Hellén); 10', Runsala (R. Frey). $N$ : 10', Porvoo (E. Suomalainen). $\mathrm{Ka}$ : 10 $0^{7}$, Vehkalahti, 1.7.1965 (L. Fagerström). Ta: 10', Kangasala (R. Frey). Oa: 10', Korsholm, 13.7.1940 (H. Lindberg). Om: 10', Jakobstad, 31.7.1949 (R. Storå). $O b: 2 \sigma^{7} \sigma^{7}$, Karlö, 12.8.1947 (R. Frey, Nyland); 10', Rovaniemi Pisa, 20.7.1950 (H. Lindberg).

Holotype and one paratype are deposited at Zoological Institute, Academy of Sciences Russia, St. Petersburg, other paratypes in Zoological Museum, University of Helsinki, Finland.

Male. Colour greenish. Body elongated, the tip of hind femur does not attain the tip of abdomen. The frons produced in front as long as the breadth of the 3rd antennal segment. Frontal triangle more high than wide at base, its surface with wrinkles. Only ocellar tubercle black. Palpi greenish. Occiput with brown central part. Mesonotal stripes black, dusted. The central stripe reaches the scutellum. Abdomen with one central black stripe. Hypopleural mark black or dark brown. Male genitalia as Fig. 3 .

The new species belongs to the group "pratorum", which consist of many closely related species, similar in general appearence. They have a rather elongated body, greenish colour, projecting frons, only central stripe on abdomen, epandrium in male genitalia with long hairs and rather long surstylus. The new species is intermediate between $M$. pratorum and $M$. sororcula. From the former it is distinguished by more narrow phallus, which is not swollen at base, and by gonite less convex on lower margin and not turned laterally at the tip. From the latter the new species is distinguished by a slightly cónvex lower margin of gonite and more rounded tip of the anterior process of gonite. 


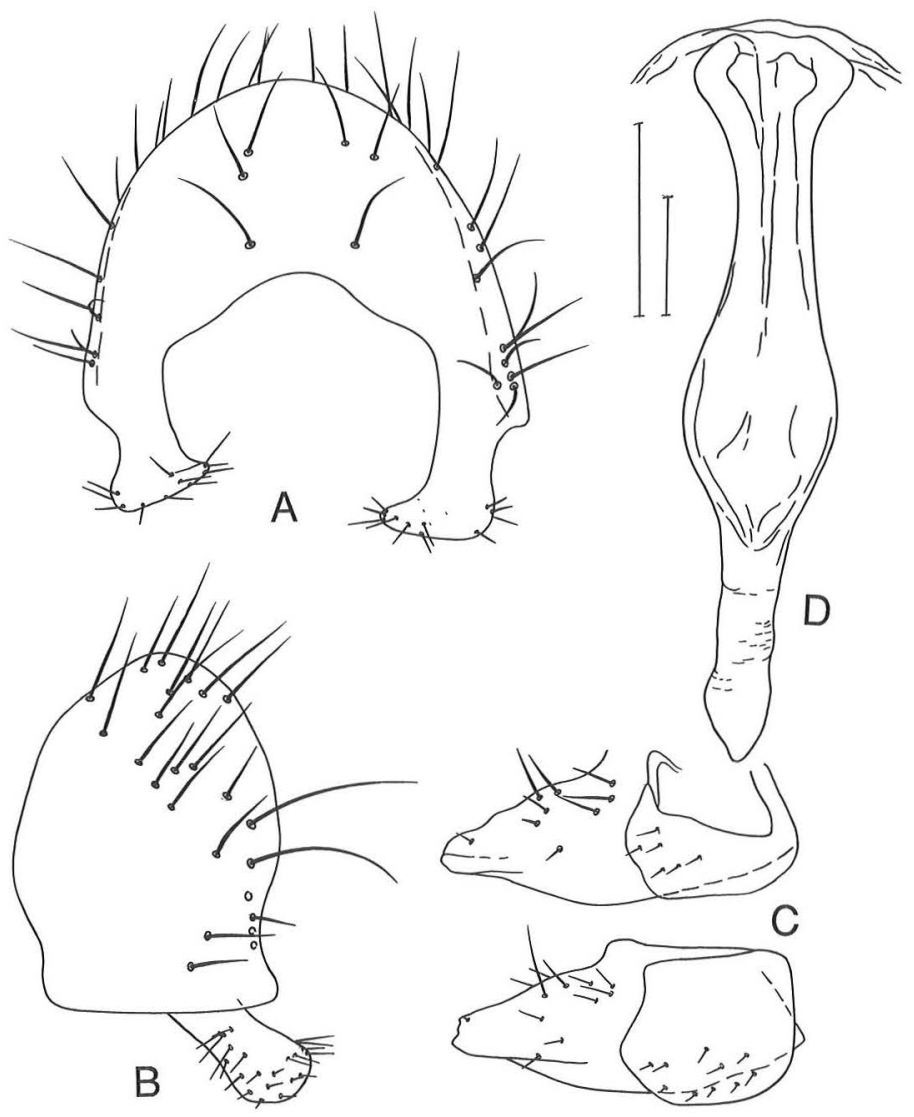

Fig. 3. Meromyza ingrica sp. $\mathrm{n} .-\mathrm{A}=$ epandrium, apical view; $\mathrm{B}=$ epandrium, lateral view; $C=$ gonite, lateral view; $\mathrm{D}=$ phallus. Scale bars $0.1 \mathrm{~mm}$ (short bar A and B, long bar C and D).

\section{M. lidiae sp. $\mathbf{n}$.}

Fig. 4

Holotype: o Finland, $N$ : Espoo Lakisto, 21.7.1985 (Nartshuk). - Paratypes: $40^{7} 0^{7}$ with the same label; $10^{7}$ Espoo, Otaniemi, 15.7.1985 (Nartshuk); $A b$ : 10', Karislojo (Hellén); $10^{7}$ Dragsfjärd, Ekhamn, 5-6.7.1961 (M. Meinander); $10^{7}$ Bobäck (R. Frey). - Russia: $10^{7} \mathrm{St}$. Petersburg Region, Kartashovka, 25.7.1926 (Stackelberg); $1 \sigma^{7}$, St. Petersburg Region, Ostrovki on Neva River, 25.7.1926 (Jacobson); $20^{7} \sigma^{\top}$ Moscow Region, Chashnikovo, 25.7 and 5.8.1957 (Fedoseeva). - Bulgaria: 20 $\sigma^{7}$, Tschepelare, 20.7.1977 (Beschovski).

Holotype is deposited in Zoological Institute, Academy of Sciences in St. Petersburg, paratypes partly at the same Institute and partly in Zoological Museum, University of Helsinki, Finland.

Male. Colour of body yellow. Frons produced in front no more than $1 / 2$ of breadth of the 3 rd antennal segment. Frontal triangle shining, rugose in apical part. Frontal triangle higher than width of base. Occiput with 2-3 brown stripes. Palpi black on the apical half. Thorax longer than wide. Mesonotal stripes black, dusted, or the central one reddish brown. Central stripe ends before the scutellum. Scutellum has a black or brown line. Pleura with brown or black marks. Abdomen with central dark stripes and small spots on 3-5 tergites. Hind femur moderately swollen, 2.5 times as thick as tibia. Male genitalia as Fig. 5. Length of body $4 \mathrm{~mm}$.

The new species is very similar to $M$. laeta Meigen. It is distinguished by the structure of male genitalia. It has surstylus more long and turned a little laterally at the tip. Gonite is larger and the tip of anterior process more pointed. The base of phallus has a process bifurcated at tip. The base of phallus of M. laeta is simple arrowshaped (Fig. 5). 
Fig. 4. Meromyza lidiae sp. n. - A = epandrium, apical view; $\mathrm{B}=$ epandrium, lateral view; $\mathrm{C}=$ gonite, lateral view; $\mathrm{D}=$ phallus. Scale bars $0.1 \mathrm{~mm}$ (short bar $\mathrm{A}$ and $\mathrm{B}$, long bar $\mathrm{C}$ and $\mathrm{D}$ ).

Fig. 5. Meromyza laeta Meigen (from Jugoslavia). - $\mathrm{A}=$ epandrium, apical view; $B$ = epandrium, lateral view; $\mathrm{C}=$ gonite, lateral view; $\mathrm{D}=$ phallus. Scale bars $0.1 \mathrm{~mm}$ (short bar $A$ and $B$, long bar $C$ and D).
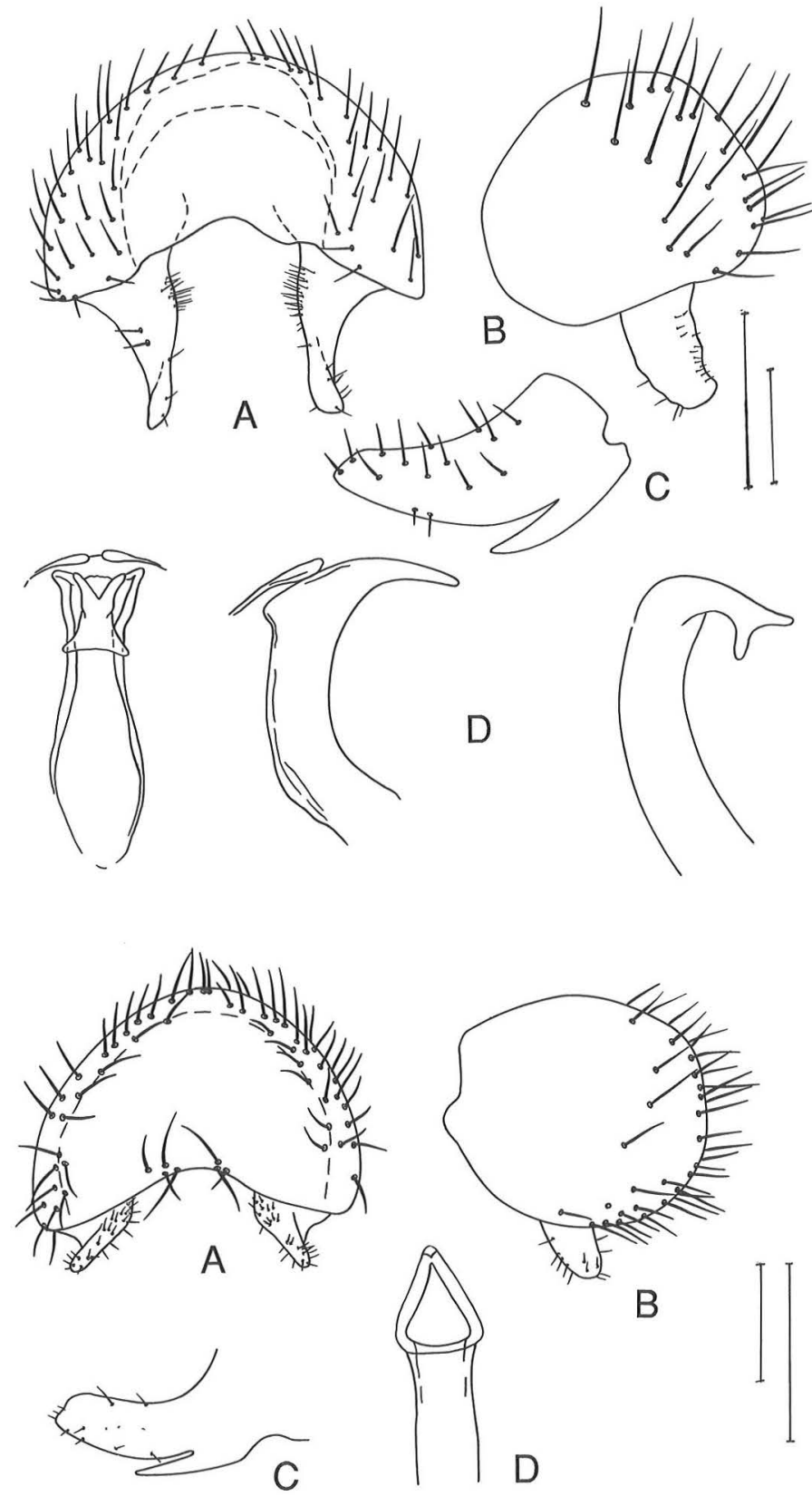

B

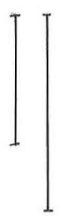

I compare the new species with the specimens of $M$. laeta from Jugoslavia collected by $\mathrm{R}$. Coe. The structure of the male genitalia of these specimens agrees well with the drawing made by J. W. Ismay on the specimen from Italy. Unfortunately the type specimen of $M$. laeta in Meigen's collection in Paris is a female (Ismay
1980). J. W. Ismay has written that it agrees with his Italian species. It is clear to me that it is necessary to consider these two species as separate ones. However, I think it will be better to examine males from the type locality of $M$. laeta - Aachen, Germany. 


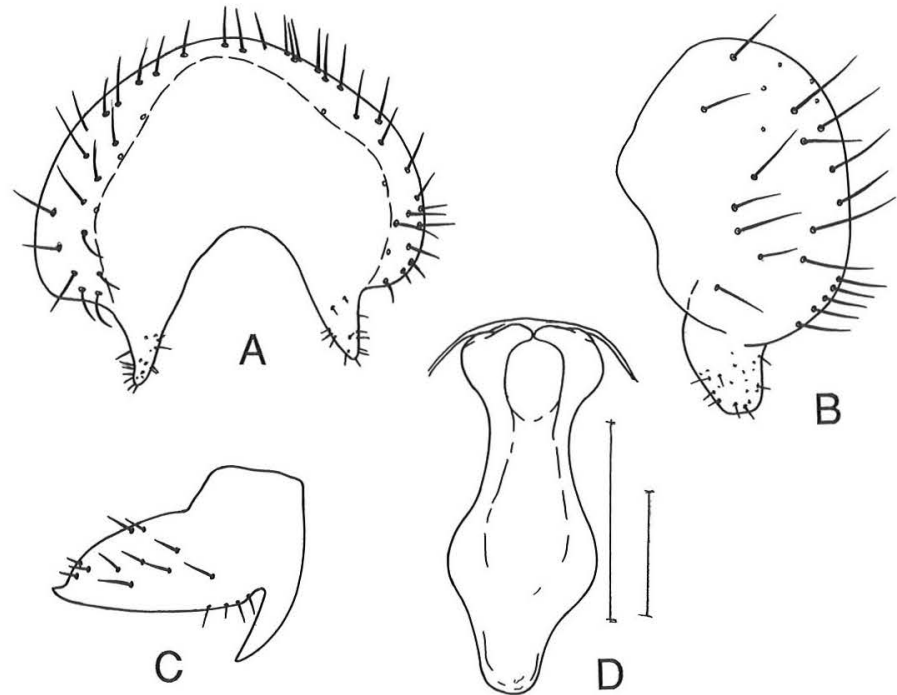

Fig. 6. Meromyza mosquensis Fedoseeva. - A = epandrium, apical view; $\mathrm{B}=$ epandrium, lateral view; $\mathrm{C}=$ gonite, lateral view; $\mathrm{D}=$ phallus. Scale bars $0.1 \mathrm{~mm}$ (short bar $\mathrm{A}$ and $\mathrm{B}$, long bar $\mathrm{C}$ and $\mathrm{D}$ ).

\section{M. mosquensis Fedoseeva}

Fig. 6

Material. Al: Föglö. Ab: Nagu. $N$ : Lappvik, Porvoo. Ta: Tavastia, Hattula. Sa: Joutseno. - Russia: Ik: Nykyrka (Polarny), Tytarsaary. Total $140^{7} \sigma^{\prime}, 1000$.

The species is not common, being collected only in southern Finland. A European species that does not occur in southern Europe.

\section{M. nigriseta Fedoseeva}

Fig. 7

Material. $A b$ : Nagu, Korpo, Dragsfjärd. $N$ : Espoo, Tvärminne, Kyrkslätt. Sa: Joutseno. Total $150^{7} 0^{7}$.

Mesonotal stripes black, but the central one at the front sometimes reddish brown, rather narrow and always reaching the scutellum. Lateral spots on 3-5 tergites of abdomen small or absent. Palpi black only at the tip.

Eurosiberian species, ranging from British Isles to Mongolia.

I have seen the holotype of $M$. nigriseta and the paratypes of $M$. coronoseta Hubicka. Number of thick bristles at the base of surstylus in male genitalia varies a little, but there are no differences in its arrangement — in rows or in a group.
I conform the synonymy $M$. nigriseta Fedoseeva 1960 and M. coronoseta Hubicka 1966.

\section{M. nigriventris Macquart}

Fig. 8

Material. Ab: Korpo. $N$ : Helsinki, Kuustö, Pargas. $T b$ :

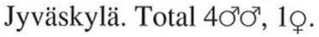

The species is rather rare in Finland and occurs only in the southern part. The dark coloured specimens determined in the collection earlier as $M$. nigriventris actually belong to $M$. pluriseta .

$M$. cerealium Reuter was described from Finland, with the type locality: "Finnland, Lofsdal im Kirchspiel Pargas (Åboskären)”. I cannot find the type specimen. The specimen with the label "Pargas, Reuter" is a female and belongs to the "pratorum" group. The specimen was investigated by M. Tschirnhaus and his label is "O Meromyza sp. 9, nicht M. cerealium Reuter, III, 1902".

As only a single Meromyza species ( $M$. nigriventris) is a pest on cereals, and because $\mathrm{E}$. Reuter wrote that the larvae of $M$. cerealinum "Lebt einzeln im Halme von Weizen und Hafer, totale Weissährigkeit Verursachen" (p. 89), the opinion of L. Fedoseeva that $M$. cerealium is a synonym of $M$. nigriventris may be accepted. 
Fig. 7. Meromyza nigriseta Fedoseeva. - A = epandrium, apical view; $B=$ epandrium, lateral view; $\mathrm{C}$ = gonite, lateral view; $\mathrm{D}=$ phallus. Scale bars $0.1 \mathrm{~mm}$ (short bar A and B, long bar C and D).

Fig. 8. Meromyza nigriventris Macquart. $-\mathrm{A}=$ epandrium, apical view; $\mathrm{B}=$ epandrium, lateral view; $\mathrm{C}=$ gonite, lateral view; $\mathrm{D}=$ phallus. Scale bars $0.1 \mathrm{~mm}$ (short bar $A$ and $B$, long bar $C$ and $D$ ).

\section{M. palposa Fedoseeva}

Fig. 9

Material. $A b$ : Pargas, Korpo, Nystad. Al: Jomala, Lumparland, Föglö, Finnström. Ta: Sysmä. $O b$ : Karlö, Hailuoto. St: Björneborg. N: Helsinge, Hangö. Total 250 $\sigma^{\top} \sigma^{\prime}$, 3oO.

European species.

C
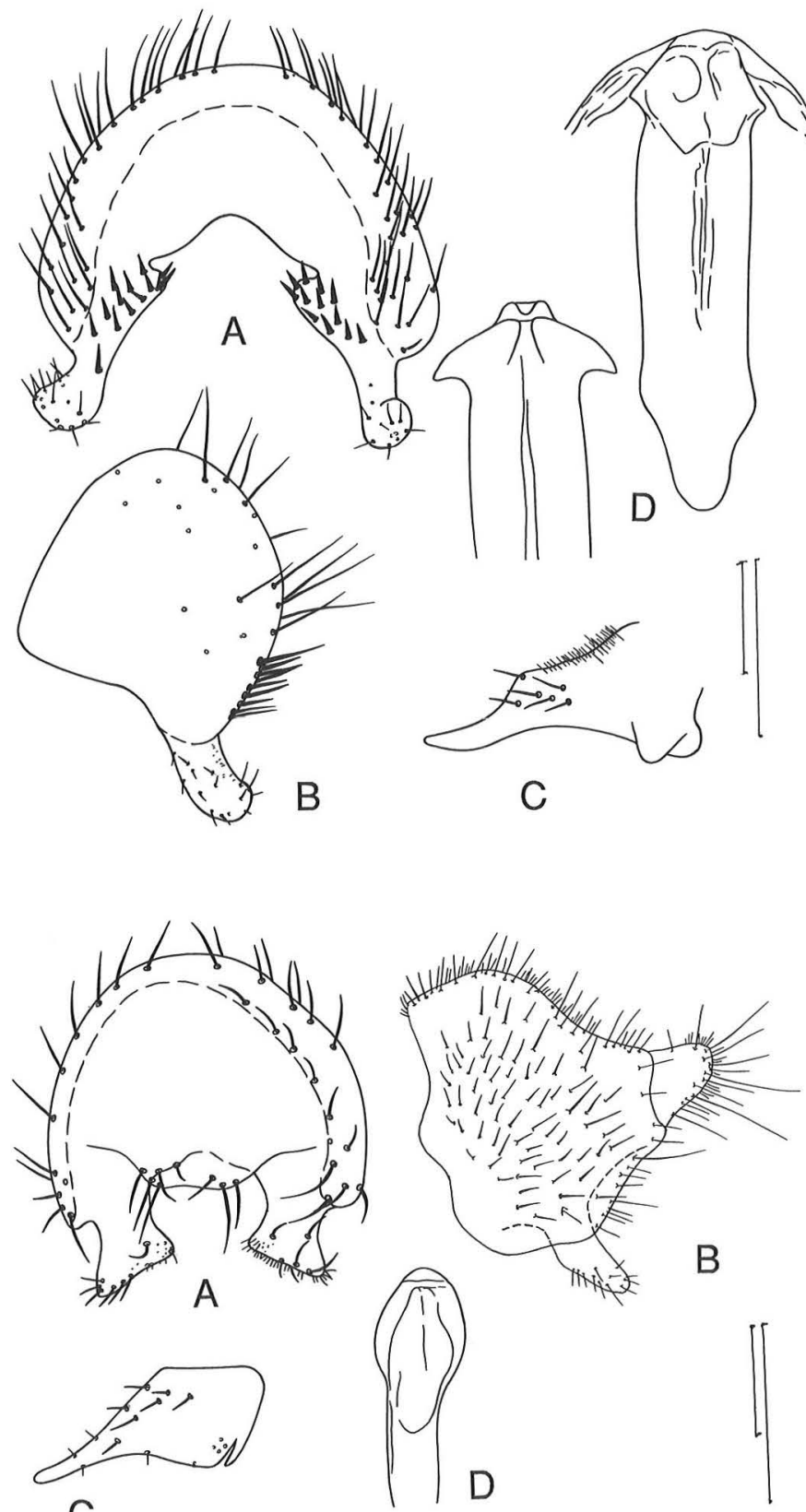

\section{M. pluriseta Péterfi}

Fig. 10

Material. Al: Eckerö, Sottunga. Ab: Korpo, Dragsfjärd, Nagu, Kimito, Pargas. N: Lappvik, Tvärminne, Hangö, Espoo, Kyrkslätt. Ka: Rajala. Ta: Forssa, Messby. Oa: Korsholm, Lapua. $O b$ : Viitasaari. $K b$ : Liperi, Hammaslahti. Om: Pedersöre, Jakobstad. $O b$ : Uleåborg, Karlö. — Russia: Valaamo, Tytarsaari. Total 50 ơం $^{\top}, 62$ фQ. 

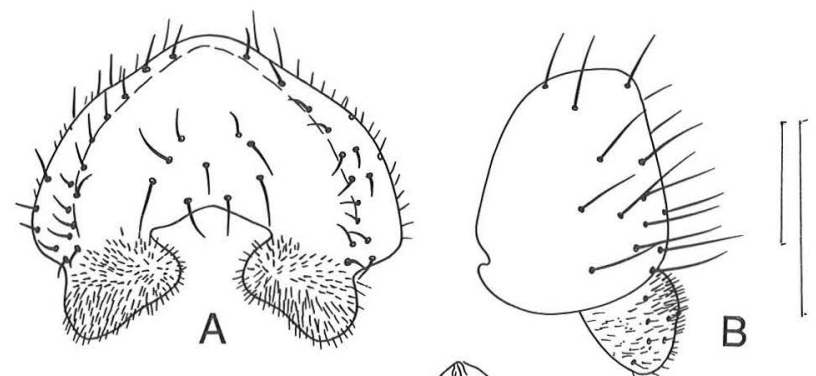

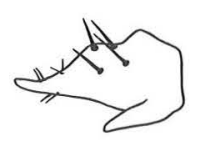

C
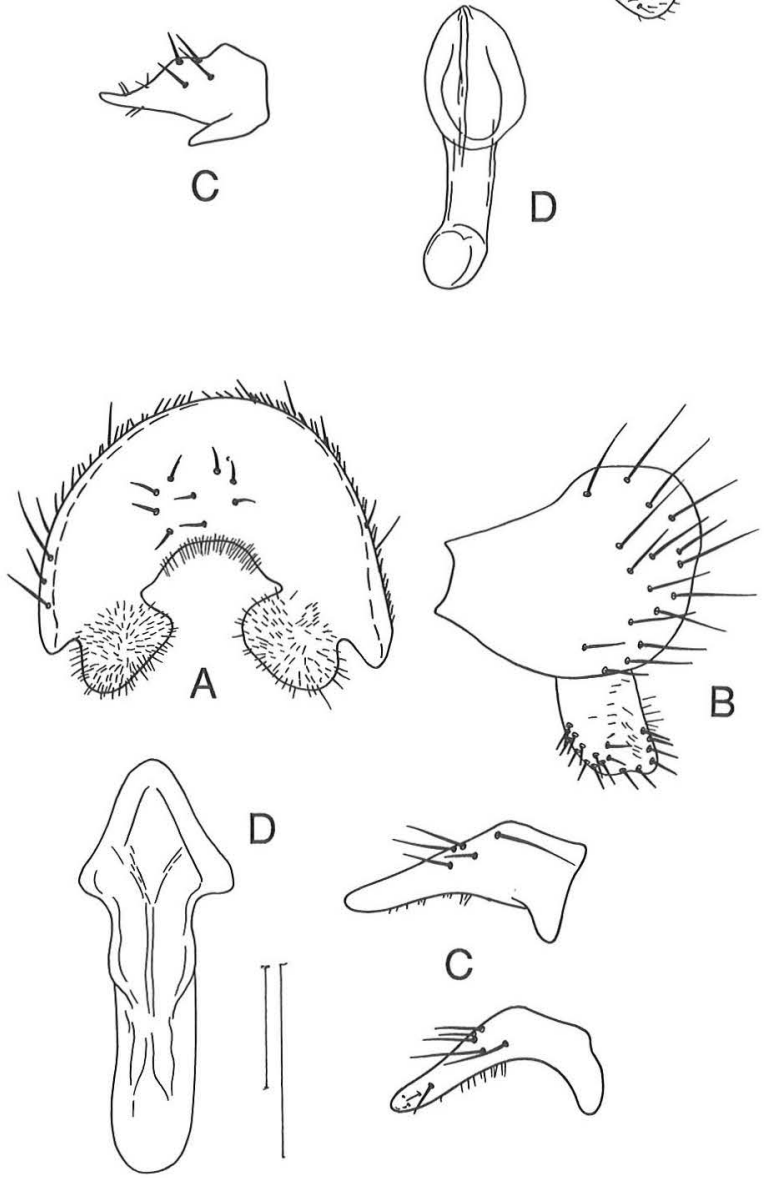

C

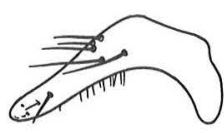

Fig. 9. Meromyza palposa Fedoseeva. $-\mathrm{A}=$ epandrium, apical view; $\mathrm{B}=$ epandrium, lateral view; $\mathrm{C}=$ gonite, lateral view; $\mathrm{D}=$ phallus. Scale bars $0.1 \mathrm{~mm}$ (short bar $A$ and $\mathrm{B}$, long bar $\mathrm{C}$ and $\mathrm{D}$ ).

Fig. 10. Meromyza pluriseta Péterfi. - $\mathrm{A}=$ epandrium, apical view; $\mathrm{B}=$ epandrium, lateral view; $\mathrm{C}=$ gonite, lateral view; $\mathrm{D}=$ phallus. Scale bars $0.1 \mathrm{~mm}$ (short bar $A$ and $\mathrm{B}$, long bar $\mathrm{C}$ and $\mathrm{D}$ ).
Colour yellow with extensive darkings. It is the darkest of the Finnish species. Palpi entirely black. Frontal triangle darkened at front of ocellar tubercle and sometimes in apical part. Abdomen dorsally sometimes entirely black. Females are rather easy to determine by the dark colour.

European-siberian species, ranging from the British Isles to Mongolia.

\section{M. pratorum Meigen}

Fig. 11

Material. Al: Hammarland. $A b$ : Dragsfjärd, Nagu, Korpo. $N$ : Hel-Loja, Nystad, Tuusula, Borgå, Liljendal, Helsinki Munkkiniemi, Espoo, Tvärminne, Lappvik, Hangö, Ekenäs. Ka: Rajala, Runsala, Vehkalahti. Ta: Sysmä, Kangasala, Forssa, Hauho. Sa: Luumäki. Tb: Keuruu, Jyväskylä. $O b$ : Rovaniemi. Norway: Herö. — Russia: Terijoki, Kuokkala, Hogland, Ollila, Rautus, Pennisaari, Tytarsaari. Total 48 o $^{7}, 50$ фO . 
Fig. 11. Meromyza pratorum Meigen. - $\mathrm{A}=$ epandrium, apical view; $\mathrm{B}=$ epandrium, lateral view; $\mathrm{C}=$ gonite, lateral view; $D=$ phallus. Scale bars $0.1 \mathrm{~mm}$ (short bar $A$ and $\mathrm{B}$, long bar $\mathrm{C}$ and $\mathrm{D}$ ).

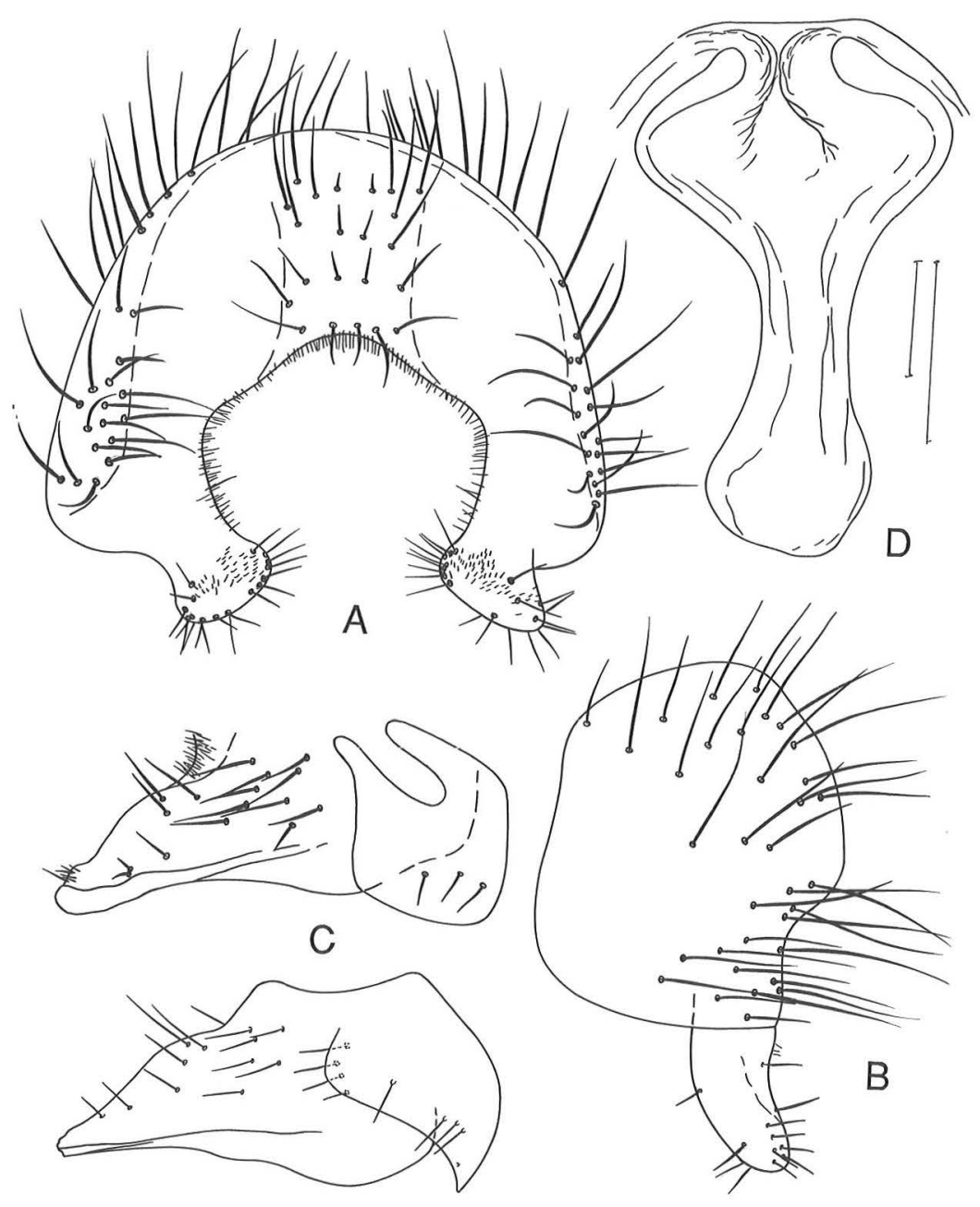

A large species with green colouration. J. W. Ismay (1980) has proposed a rather good feature to distinguish this species from the related $M$. sororcula - red colour of hypopleural mark. But a few Finnish specimens of $M$. pratorum have dark brown or black hypopleural mark.

Holarctic species.

\section{M. rohdendorfi Fedoseeva}

Fig. 12

Material. $A b$ : Nagu, Dragsfjärd. Total $20^{7} \sigma^{7}$.

European species. In Finland rather rare, found only in Varsinais-Suomi.

\section{M. rostrata Hubicka}

Fig. 13

\section{Material. $A b$ : Karislojo. $1 \sigma^{\prime}$.}

The species was described from Poland (Hubicka 1966). I have not seen the type, but the structure of the male genitalia agrees well with the drawing by Hubicka. It is the second specimen of this rare species found.

\section{M. saltatrix Linnaeus}

Fig. 14

Material. Al: Föglö, Jomala. Ab: Björkö, Nystad, Uskela, Nagu, Korpo, Dragsfjärd. N: Helsinki, Espoo, 

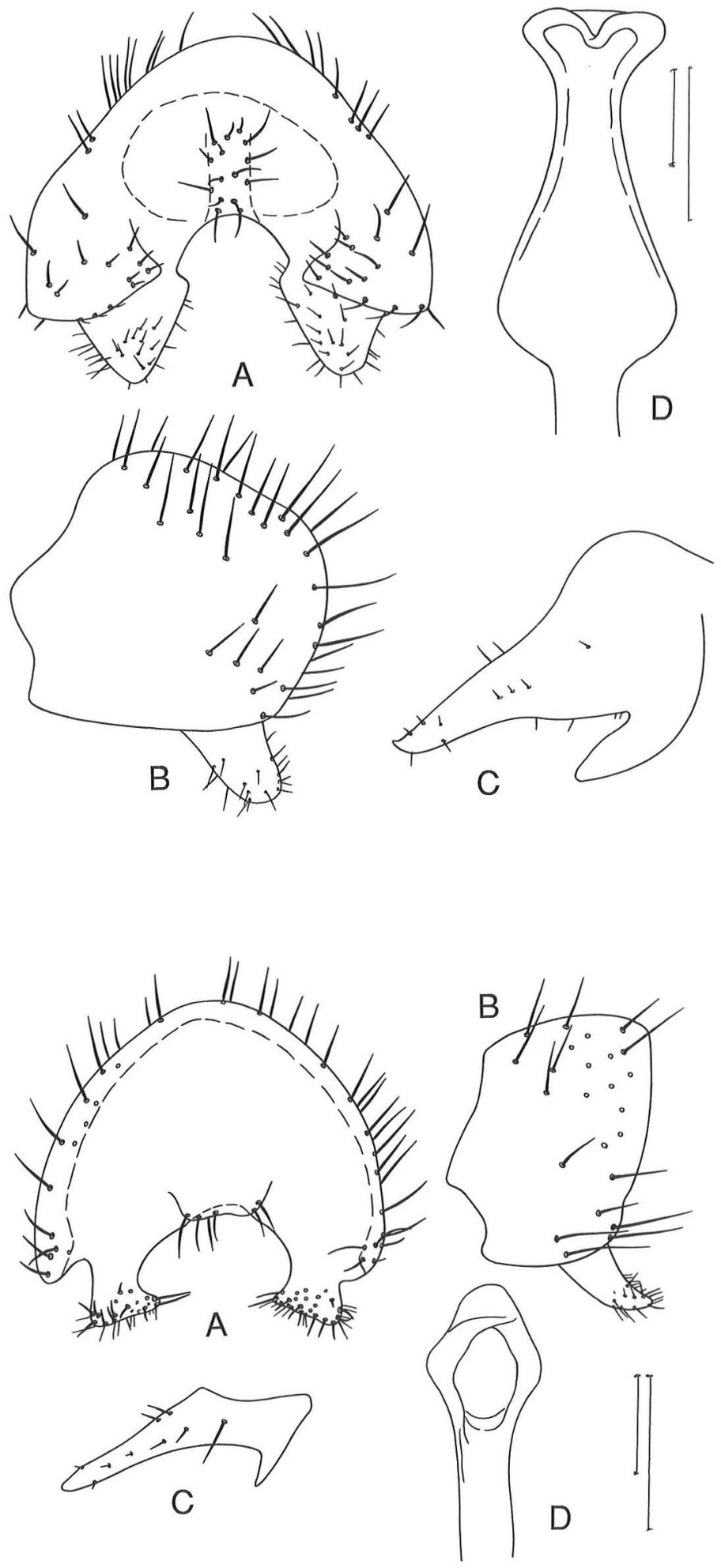

Fig. 12. Meromyza rohdendorfi Fedoseeva. - A = epandrium, apical view; $\mathrm{B}=$ epandrium, lateral view; $\mathrm{C}=$ gonite, lateral view; $\mathrm{D}=$ phallus. Scale bars $0.1 \mathrm{~mm}$ (short bar A and $\mathrm{B}$, long bar $\mathrm{C}$ and $\mathrm{D}$ ).

Fig. 13. Meromyza rostrata Hubicka. - $A=$ epandrium, apical view; $B=$ epandrium, lateral view; $\mathrm{C}$ = gonite, lateral view; $\mathrm{D}=$ phallus. Scale bars $0.1 \mathrm{~mm}$ (short bar A and B, long bar C and D). 
Fig. 14. Meromyza saltatrix Linnaeus. $-\mathrm{A}=$ epandrium, apical view; $\mathrm{B}=$ epandrium, lateral view; $\mathrm{C}=$ gonite, lateral view; $\mathrm{D}=$ phallus. Scale bars $0.1 \mathrm{~mm}$ (short bar $A$
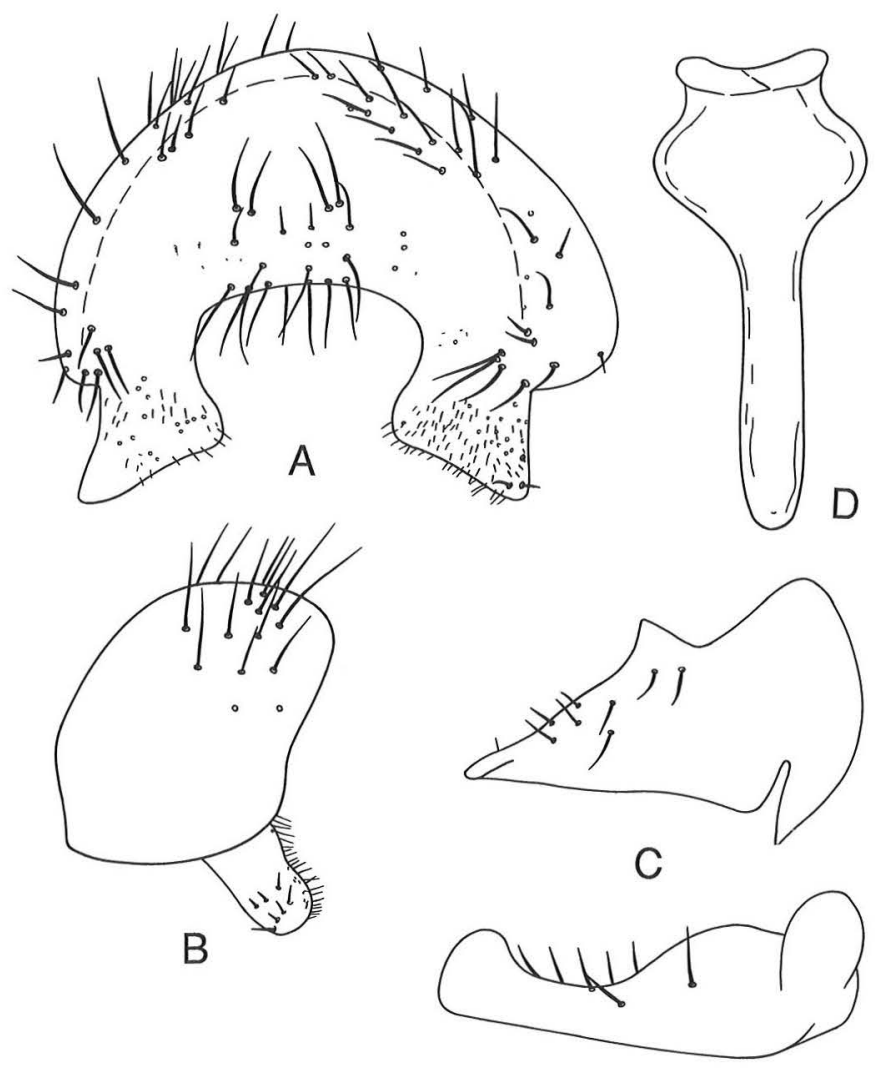
and $\mathrm{B}$, long bar $\mathrm{C}$ and $\mathrm{D}$ ).

Ekenäs, Tvärminne, Hangö, Porvoo, Kyrkslätt. Ka: Kivikoski, Vehkalahti. Ta: Kalvola, Kangasala. Sa: Joutseno. Oa: Korsholm, Peplot, Lappo, Wasa. Tb: Viitasaari, Keuruu. Sb: Jorois. $K b$ : Eno. $O b$ : Uleåborg. $L k$ : Muonio. $L e$ : Enontekiö. $L i$ : Enare, Salmi. — Russia: Valamo, Pulkova, Kandalahti (= Kandalahsha), Kivinebb (=Pervomaiskoe), Impilaks, Karjavalaks (=Sortavala), Vuokkiniemi, Kenjarvi, Nykyrka. Numerous ơ’’.

Holarctic species. One of the most common species in Finland and in Palaearctic as well.

\section{Meromyza sibirica Fedoseeva}

Fig. 15

The species is rather rare. In East Europe only a few specimens are collected in Estonia and Russia (vicinity of St. Petersburg, Moscow and Rjazan). It is more common in the Asian part of the Palearctic: in West and East Siberia, North Kazakhstan, Mongolia and Japan. The species may well be found in Finland.

\section{M. sororcula Fedoseeva}

Fig. 16

Material. $A b$ : Korpo, Nagu, Dragsfjärd, Pargas, Uskela (= Salo), Lohja, Vihtijärvi. $N$ : Helsinki, Tvärminne, Ekenäs, Espoo. $O b$ : Turtola (= Pello), Karlö (= Hailuoto). $O m$ : Jakobstad (= Pietarsaari). Ta: Hattula, Sääksmäki. Sa: St. Michel. St: Ahlainen, Reposaari. Ka: Rajala. — Russia: Seikaari, Hogland, Syvari, Viete. Total 43 ơ Ơ, 27 oo.

Euro-siberian species, ranging from the British Isles to Mongolia. One of the commonst species in the Finnish collection.

\section{M. triangulina Fedoseeva}

Fig. 17

Material. Al: Eckerö, Finström. Ab: Pargas, Nystad, Korpo, Nagu, Runsala. $N$ : Ekenäs (= Tammisaari), Tvärminne, Helsinki, Espoo, Ruotsinpyhtää. St: Ytterö. Sweden: Eriksberg. — Russia: Tjudi. Total 28 ơ $^{\top}, 19$ ○o. 


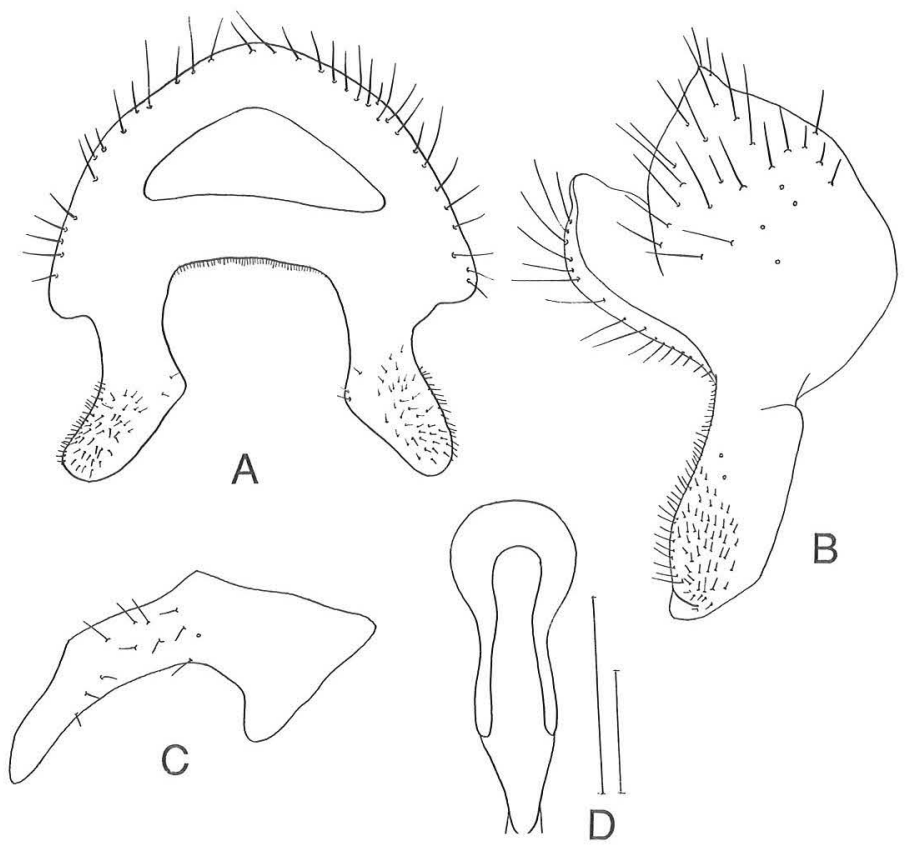

Fig. 15. Meromyza sibirica Fedoseeva. - A = epandrium, apical view; $\mathrm{B}=$ epandrium, lateral view; C = gonite, lateral view; $\mathrm{D}=$ phallus. Scale bars $0.1 \mathrm{~mm}$ (short bar A and B, long bar C and D).
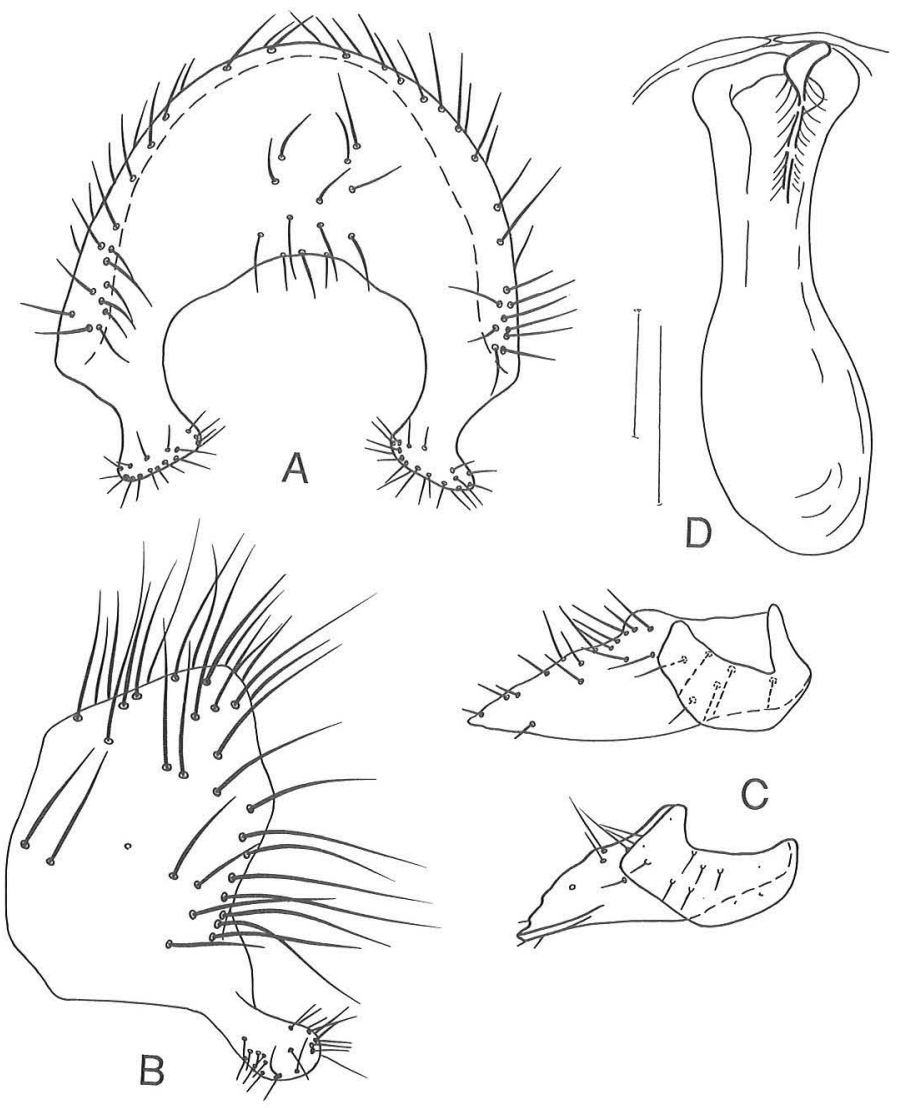

Fig. 16. Meromyza sororcula Fedoseeva. $-\mathrm{A}=$ epandrium, apical view; $\mathrm{B}=$ epandrium, lateral view; $\mathrm{C}=$ gonite, lateral view; $\mathrm{D}=$ phallus. Scale bars $0.1 \mathrm{~mm}$ (short bar $\mathrm{A}$ and $\mathrm{B}$, long bar $\mathrm{C}$ and D). 
Fig. 17. Meromyza triangulina Fedoseeva. $-\mathrm{A}=$ epandrium, apical view; B = epandrium, lateral view; $\mathrm{C}=$ gonite, lateral view; $\mathrm{D}$ $=$ phallus. Scale bars 0.1 $\mathrm{mm}$ (short bar $\mathrm{A}$ and $\mathrm{B}$, long bar $\mathrm{C}$ and $\mathrm{D})$.
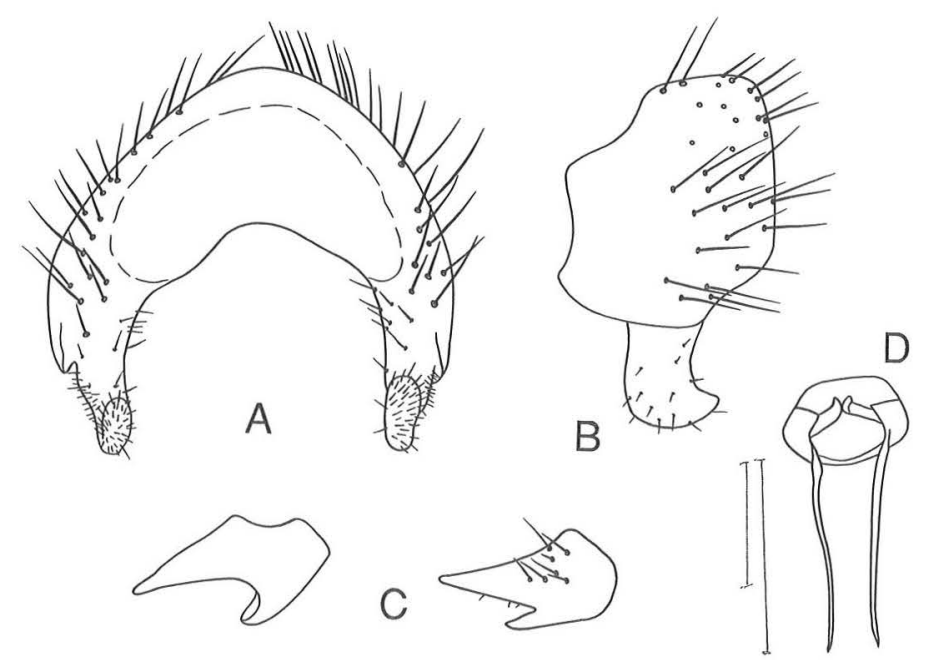

The species is small and is easily distinguished by dark lateral sides of frontal triangle, black hairs on cheek and black hairs (not thick bristles) on epandrium. Hind femora rather narrow.

European species.

\section{M. zimzerla sp. n.}

Fig. 18

Holotype: $0^{7}$ Russia, St. Petersburg Region, Tolmatchevo, 20.VII.1960 (Nartshuk). - Paratypes: Russia: $100^{7} 0^{7}, 500$ with the same label, 13.7-20.7.1960; 60 0', 4oo, St. Petersburg Region, Jashchera, Luga Districh, 2628.7.1960 (Stackelberg); 10', Moscow Region, Dedinovo, 23.6.1954, ex larva from shoot of Phleum pratense (Nartshuk). - Estonia: 150 $0^{7}, 900$, Saaremaa, Natural Reserve Vidumjae, 25.7-3.8.1987 (Nartshuk); $10^{77}$ Saaremaa, Valjala, 22.7.1987 (Nartshuk). — Latvia: 10', 1o, Garupe, 9.7.1975 (Karps). — Finland: $20^{7} \sigma^{7}$ Espoo, Otaniemi, 10.7, 21.7.1985 (Nartshuk); $10^{7}$ Espoo, Lakisto, 21.7.1985 (Nartshuk); 20 $\sigma^{\top}, 10$ Rajala Saima Kanal, 3.6.1908 (Adelung); $10^{\text {T }}$ Mariehamn, 29.7.1942 (H.

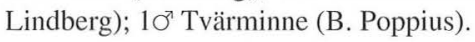

Holotype and most of the paratypes are deposited in Zoological Institute, Academy of Sciences of Russia in St. Petersburg, and some of the paratypes in Zoological Museum, University of Helsinki, Finland.

Male. Colour of body yellow. Frons produced in front not more than $1 / 2$ of breadth of the $3 \mathrm{rd}$ antennal segment. Frontal triangle shining, rugose in anterior part. Only ocellar tubercle black. Occiput with two narrow brownish lines. Palpi yellow. Thorax longer than wide. Mesonotal stripes from black to reddish brown. The central one ends before the scutellum. Scutellum yellow. Pleura with red sternopleural mark and brown hypopleural mark. Abdomen with a central black or brown line and lateral spots on 4-5 tergites. Hind femur 3 times as thick as hind tibia. Male genitalia as Fig. 19. Length of body $4 \mathrm{~mm}$.

The new species is rather similar to $M$. variegata but is easily distinguished by the structure of male genitalia. Main differences are form of surstylus and phallus. Surstylus is small in $M$. variegata and long and turned a little laterally in the new species. Phallus of $M$. variegata has a process at the base, while the new species is simple at base. Form of gonite of both species is rather similar.

I have not seen the type of $M$. variegata but J. W. Ismay (1980) has examined the type (male) from Meigen's collection in Paris and illustrated the male genitalia. I compare the new species with $M$. variegata from the Crimea (Ukraine) (Fig. 19). Male genitalia of Crimean specimen agree well with Ismay's figures.

I have some specimens of the new species from the St. Petersburg region and have swept a lot of specimens on Saarema Island (Estonia). They have been swept on a dry meadow with Phleum phleoides.

The question of host plants of $M$. variegata needs clarification after the distinguishing of these 

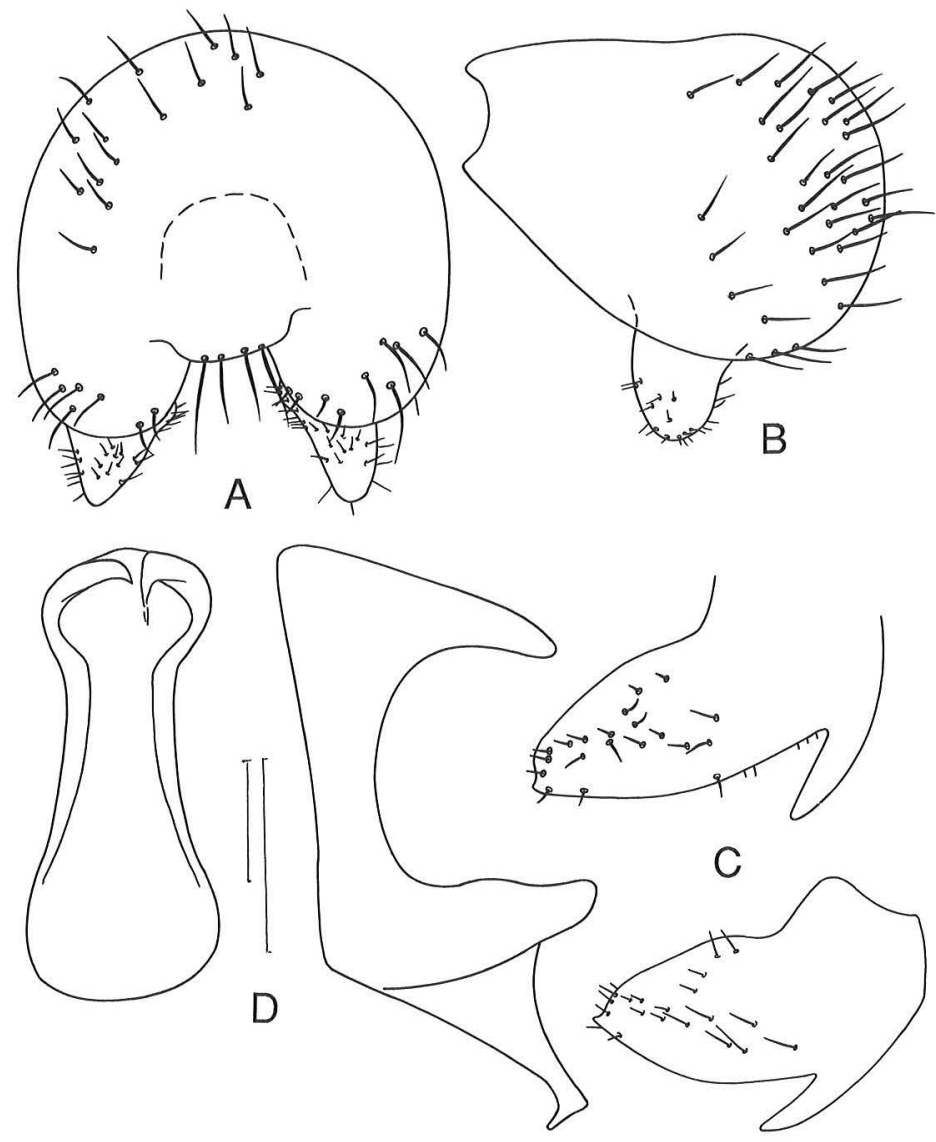

Fig. 18. Meromyza variegata Meigen (from the Crimea). $-A=$ epandrium, apical view; $B=$ epandrium, lateral view; $\mathrm{C}=$ gonite, lateral view; $\mathrm{D}=$ phallus. Scale bars $0.1 \mathrm{~mm}$ (short bar A and B, long bar $\mathrm{C}$ and $\mathrm{D}$ ).

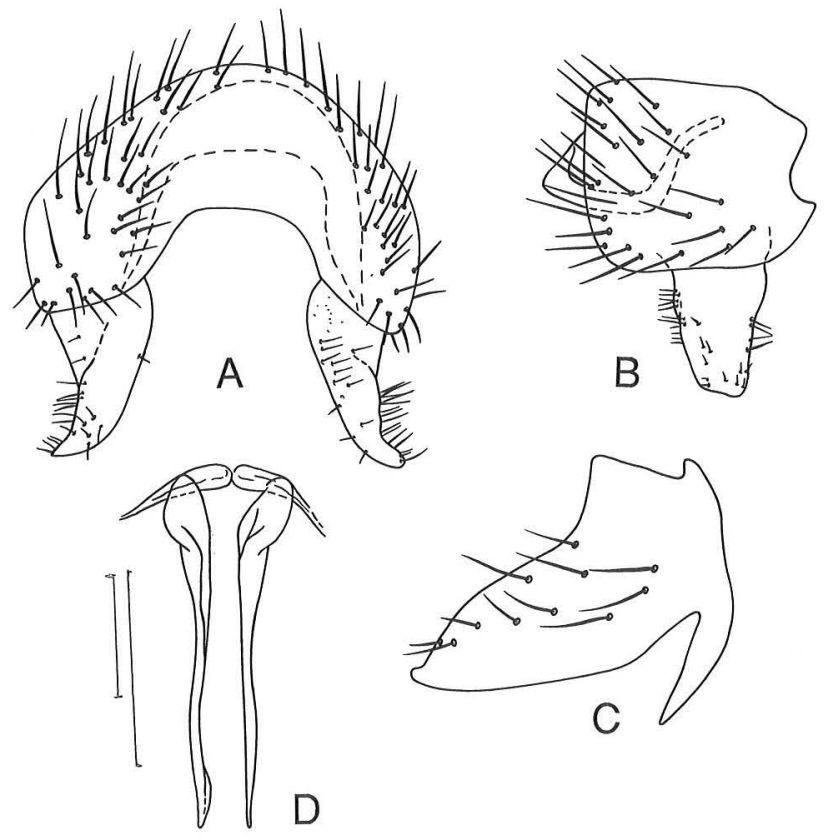

Fig. 19. Meromyza zimzerla sp. n. - A = epandrium, apical view; $B=$ epandrium, lateral view; $C$ = gonite, lateral view; $D=$ phallus. Scale bars $0.1 \mathrm{~mm}$ (short bar A and B, long bar C and D). 
two species. Many authors in Western Europe record Dactylis glomerata as a single host plant of $M$. variegata, but L. I. Fedoseeva (1960) considered Phleum pratense as a host plant of $M$. variegata. The new species $M$. zimzerla Nartshuk corresponds to $M$. variegata sensu Fedoseeva, not Meigen. It feeds as a larva in shoots of Phleum pratense and Ph. phleoides.

Acknowledgements. I am greatly indebted to Dr. B. Lindeberg and Ms. G. Ståhls for making this interesting material available for study.

\section{References}

Andersson, H. 1966: A revision of the species of Oscinides described by J. W. Zetterstedt (Dipt. Chloropidae). Opusc. Entomol. 31:61-76.

Beschovsky, V. 1985: Diptera, Chloropidae. - Fauna of Bulgaria. Sofia. 14. 219 pp. (in Bulgarian)

Dely-Draskovits, A. 1978: Chloropidae - Gabonalegyek. (in Hungarian) - Fauna Hungariae 133:61-194. Budapest.

Duda, O. 1932-1933: Chloropidae. — In: Lindner, E. (ed.), Die Fliegen der Palaearktischen Region. 6(1):1-248.

Fedoseeva, L. I. (Федосеева, Л. И.) 1960: The species of the genus Meromyza Meig. (Diptera, Chloropidae) in the environs of Moskow. (In Russian) - Entomol. Obozr. 39(2):450-461.
Frey, R. 1908: Beiträge zur Kenntnis der Dipteren-Fauna Finnlands. - Meddel. Soc. Fauna Flora Fennica 33(1907):67-69.

Hackman, W. 1980: A check list of the Finnish Diptera. II. Cyclorrhapha. - Notulae Entomol. 60:117-162.

Hubicka, J. 1966: New species of the genus Meromyza Mg. (Diptera, Chloropidae) from Poland. - Ann. Univ. Marie Curie-Składowska, Biol. 21(2):13-26.

Ismay, J. W. 1981: British Meromyza (Dipt., Chloropidae). — Entomol. Monthly Mag. 116:177-197.

Karps, A. E. 1981: [Chloropid flies (Diptera) of Latvia]. (In Russian) - Autoreferat Kand. Thesis. Kiev. 23 pp.

Nartshuk, E. P. (Нарчук, Э. П.) 1972: [Phytophagy of Chloropidae (Diptera) and its evolution.] (In Russian) - Report on the 23th annual reading in the memory of N. A. Cholodkovskogo. Nauka. Leningrad, 3-94.

- 1984: Chloropidae. - Catalogue of Palaearctic Diptera. Clusiidae - Chloropidae 10:222-298.

Nartshuk, E. P. \& Elberg, К. (Нарчук, Э. П. \& Эльберг, К.) 1979: List of the Chloropid flies (Diptera) of Estonia. (In Russian with English summary) — Dipteroloogilisti uurimusi: 122-143. Tartu.

Reuter, F. 1902: Meromyza cerealium n. sp. ein neuer Getreideschädiger. - Meddel. Soc. Fauna Flora Fennica 28(B):84-91.

Stackelberg, A. A. 1965: New data on the fauna of Diptera of Leningrad Region. (In Russian) — Latvijas Entomol. 10:61-71.

Received 4.X.1990

Appendix. Distribution of Meromyza species in Finland.
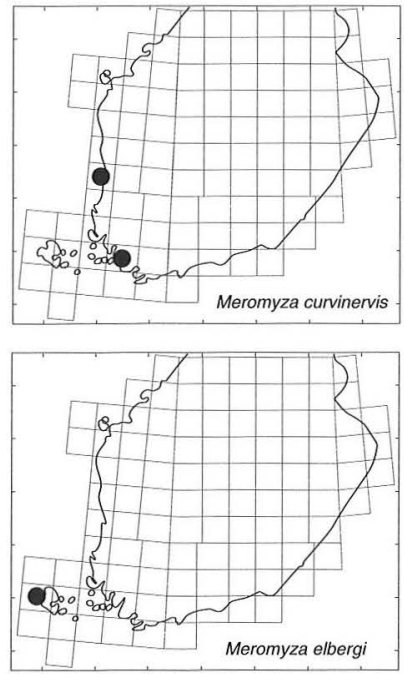

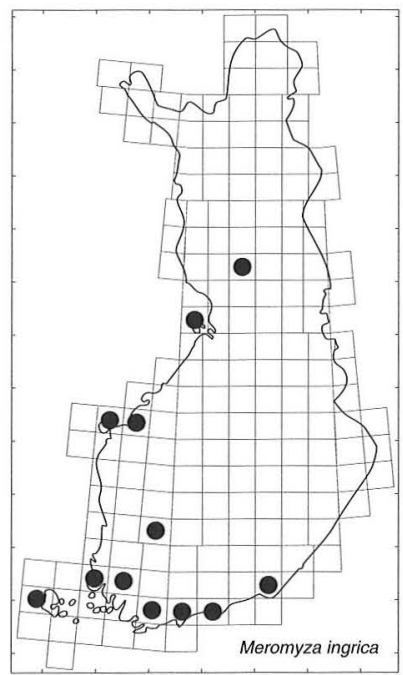

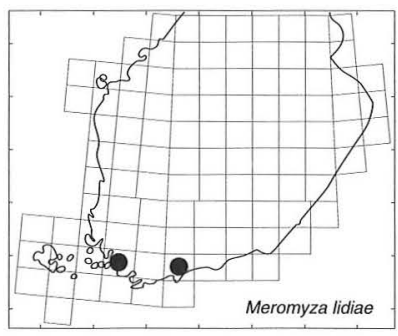

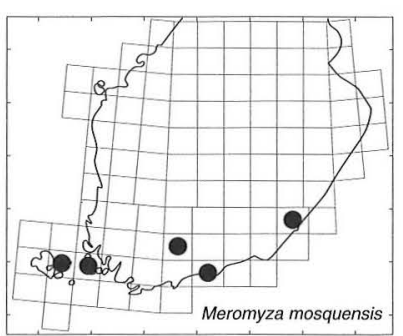



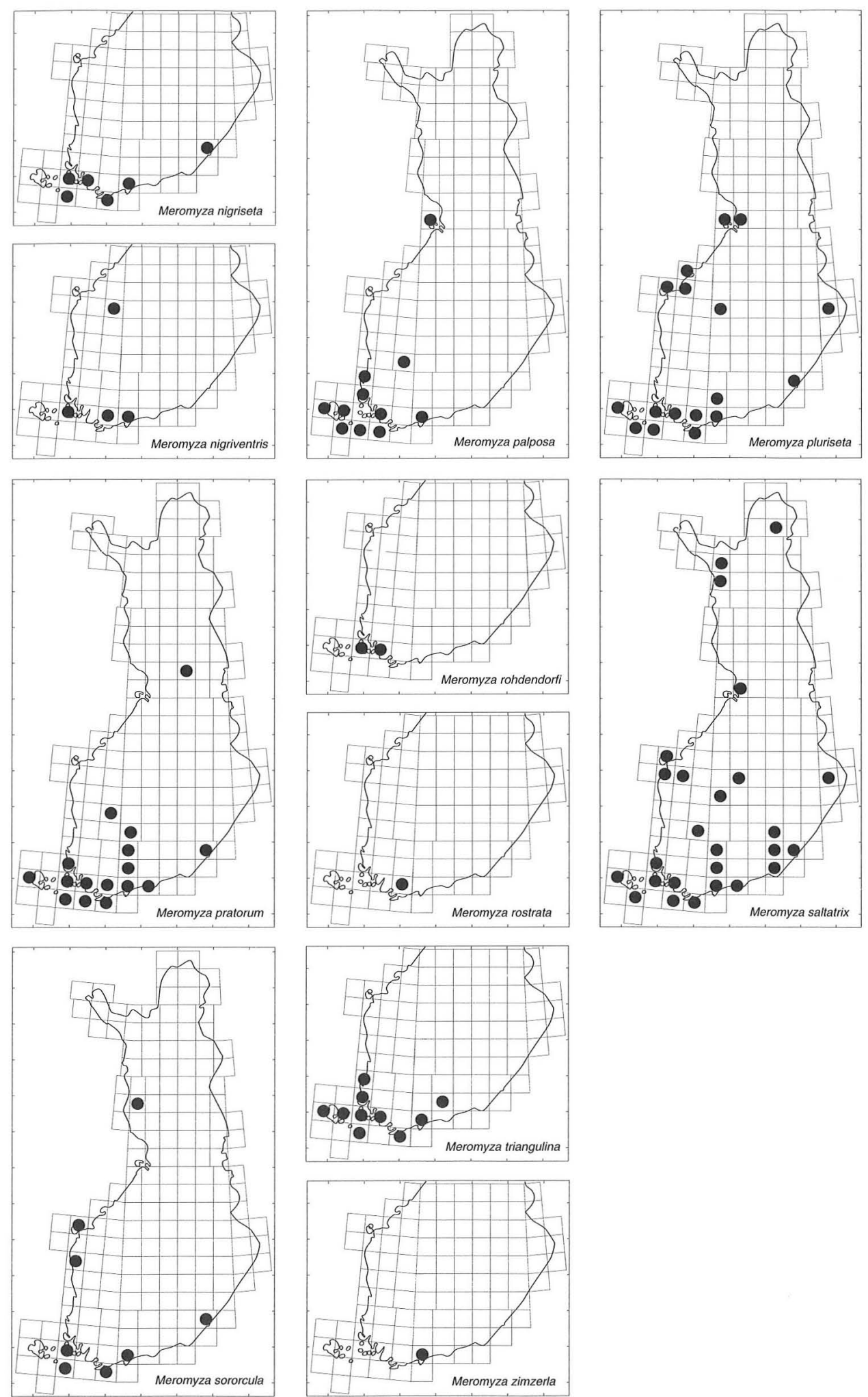